\title{
VARYING CONDITIONS IN INTERTIDAL POOLS: HIGH RESOLUTION pH DYNAMICS AND PRIMARY PRODUCTION
}

\author{
Celso A. Hernández Díaz* \& José Carlos Hernández
}

\begin{abstract}
Most studies designed to assess the effects of ocean acidification take place in coastal and intertidal environments, which are characterized by a great variability of its physical and chemical parameters. However, a great number of these studies use fixed $\mathrm{pH}$ levels predicted for the future, disregarding natural $\mathrm{pH}$ oscillations. In this work we studied the $\mathrm{pH}$ oscillations and primary productivity of intertidal rockpools in two rocky shore areas. To provide high resolution continuous $\mathrm{pH}$ data we used an autonomous $\mathrm{pH}$ measuring system which consisted of a $\mathrm{pH}$ sensor, a data logger and a battery encased in a waterproof container. Oxygen concentration and primary production from phytoplankton and macro-phytobentos were also measured. We found a range of $\mathrm{pH}$ variation in the pools of 0.07 $\mathrm{pH}$ units/day when water dynamics was high and of $0.26 \mathrm{pH}$ units/day when conditions were more stable. Carbonate systems parameters, temperature and oxygen concentration were related and they responded to the day / night cycle and hydrodynamic conditions. We suggest that these natural oscillations in $\mathrm{pH}$ and temperature must be taken into account in ocean acidifications studies in order to obtain more accurate results.
\end{abstract}

KeYwORDs: $\mathrm{pH}$ variability, intertidal pools, macroalgae, phytoplankcton.

\section{CONDICIONES VARIABLES EN CHARCOS INTERMAREALES: DINÁMICAS DE ALTA RESOLUCIÓN DEL $\mathrm{pH}$ Y PRODUCTIVIDAD PRIMARIA}

\section{RESUMEN}

La mayoría de los estudios diseñados para evaluar los efectos de la acidificación oceánica son llevados a cabo en ambientes costeros e intermareales, que se caracterizan por una gran variabilidad de sus parámetros físicos y químicos. Sin embargo, una gran cantidad de estos estudios utiliza niveles fijos de $\mathrm{pH}$ previstos para el futuro, sin tener en cuenta las variaciones naturales de $\mathrm{pH}$. En este trabajo estudiamos la variación del $\mathrm{pH}$ y la producción primaria en una serie de charcos intermareales de dos zonas costeras rocosas. Utilizamos un sistema autónomo de medida para obtener un registro continuo de $\mathrm{pH}$. También se midieron la concentración de $\mathrm{O} 2$ y la producción primaria del fitoplancton y del macrofitobentos. Encontramos una amplia variación diaria del $\mathrm{pH}$ en los charcos intermareales, de 0.26 unidades de $\mathrm{pH} /$ día en condiciones de baja hidrodinámica marina y de 0.07 unidades / día en condiciones de alta hidrodinámica. Los parámetros del sistema del carbonato, temperatura y concentración de $\mathrm{O} 2$ se mostraron dependientes del ciclo día/noche y de las condiciones hidrodinámicas. Proponemos tener en cuenta estas oscilaciones de $\mathrm{pH}$ y temperatura en el diseńo de los estudios sobre la acidificación del medio marino para obtener resultados más precisos y realistas. PALABras Clave: variabilidad del $\mathrm{pH}$, charcos intermareales, macroalgas, fitoplancton.

DOI: http://doi.org/10.25145/j.SI.2018.01.008

Revista Scientia Insularum, 1; diciembre 2018, pp. 123-138; ISSN: e-2659-6644 


\section{INTRODUCTION}

Since the beginning of the Industrial Revolution, with the increase in use of steam power with carbon as a main source of energy for human activities, followed by petroleum and natural gas, anthropogenic $\mathrm{CO}_{2}$ emissions related to the use of fossil fuels have caused an increase of atmospheric $\mathrm{CO}_{2}$ concentration from 280 ppmv (parts per million volume) (Le Querè et al. 2009) to 404 ppmv (NOAAESRL, 2016). This $\mathrm{CO}_{2}$ concentration is likely to exceed 1000 ppmv by the year 2100 (Meehl et al. 2007; Fabry et al. 2008) if anthropogenic $\mathrm{CO}_{2}$ emissions are not significantly reduced. Based on this increase of $\mathrm{CO}_{2}$ and other greenhouse gasses, a rise in air temperature of 2.6 to $4.8^{\circ} \mathrm{C}$ (IPCC 2014) and of $1^{\circ} \mathrm{C}$ to $7^{\circ} \mathrm{C}$ in surface sea water temperature (Houghton et al. 2001) has been predicted for the year 2100. The increased concentration of atmospheric $\mathrm{CO}_{2}$ has caused a shift in the oceans: from a net source of $\mathrm{CO}_{2}$ to the atmosphere to a $\mathrm{CO}_{2}$ sink. Since 1800 , oceans have taken up about $24 \%$ of the anthropogenic $\mathrm{CO}_{2}$ emissions (Canadell et al. 2007). This has produced a series of alterations in the oceanic carbonate system, known as Ocean Acidification (OA): when $\mathrm{CO}_{2}$ dissolves in seawater, it reacts with water forming carbonic acid $\left(\mathrm{H}_{2} \mathrm{CO}_{3}\right)$ which immediately dissociates and loses hydrogen ions $\left(\mathrm{H}^{+}\right)$resulting in the formation of bicarbonate $\left(\mathrm{HCO}^{3-}\right)$ and carbonate $\left(\mathrm{CO}_{3}^{2-}\right)$ ions. This causes an increase of $\mathrm{H}^{+}$, which lowers the seawater $\mathrm{pH}$. Over the last 200 years, ocean $\mathrm{pH}$ is thought to have decreased by approximately 0.1 units, from 8.21 to 8.07 (Royal Society 2005; Kleypas 2006). Current mean ocean pH is 8.07 (Hall-Spencer et al. 2008) and it is predicted that $\mathrm{pH}$ will decrease by a further $0.3-0.5$ units by the end of the 21st century (Gattuso and Hansson 2011; Gruber et al. 2012). These changes in the chemical equilibrium of seawater have caused a decrease in the saturation states of calcite and aragonite, which can cause negative effects on calcifying organisms (Orr et al. 2005; Kroeker et al. 2011; Doney et al. 2012), many of which live in coastal habitats.

Coastal ecosystems are characterized by pronounced temporal and spatial variability in carbonate chemistry and $\mathrm{pH}$ (Hofmann et al. 2011; Mercado and Gordillo 2011; Duarte et al. 2013). In these environments in particular, variability may be amplified due to the ambient heterogeneity and biological activity (Middelboe and Hansen 2007). There is a relationship between the biological activity of primary producers and the variability of seawater $\mathrm{pH}$. For example, Mediterranean Posidonia oceanica meadows are able to modify $\mathrm{pH}$ in the water column by 0.2 to $0.7 \mathrm{pH}$ units in a day through photosynthetic activity and community respiration (Frankignoulle and Distèche 1984; Frankignoulle and Bouquegneau 1990; Invers et al. 1997). In the open ocean, diurnal variation is not as pronounced: an average

* Departamento de Biología Animal, Edafología y Geología, Facultad de Ciencias (Sección Biología), Universidad de La Laguna, Tenerife, Canary Islands, Spain. Corresponding author: cahernan@ull.edu.es. 
$\mathrm{pH}$ range of 0.024 units is more typical (Hoffmann et al. 2011). The metabolic activity of primary producers in productive habitats can raise $\mathrm{pH}$ during the day to higher levels, providing mitigation from the negative effects of $\mathrm{OA}$ to the organisms inhabiting these systems. For example, high $\mathrm{pH}$ associated to photosynthesis has been related to enhanced calcification rates of calcareous algae in a tropical seagrass bed (Semesi et al. 2009).

The effects of ocean acidification on marine ecosystems have been an important research area during the last years. Numerous laboratory studies have been published showing evidence that ocean acidification influences development, growth, physiology and survival of marine organisms, especially calcifying species (Orr $e t a l$. 2005; Fine and Tchernov 2007; Ries et al. 2009; Dupont et al. 2013). These studies have demonstrated a wide range of responses to seawater acidification by different taxonomic groups (Doney et al. 2009; Kroeker et al. 2013). However, most studies designed to identify the effects of ocean acidification use already available average values of carbon chemistry parameters $(\mathrm{pH}$, total alkalinity, $p \mathrm{CO} 2$ and dissolved inorganic carbon), instead of measuring them in situ (McElhany and Busch 2012). Separate studies, specifically measuring $\mathrm{pH}$ and carbonate levels in the same habitats, often result in values that are inconsistent with the used $p \mathrm{CO}_{2}$ averages. Experiments designed to assess the impact of ocean acidification should therefore also measure carbon chemistry within the studied habitats of the model species used.

Intertidal pools are one of the marine environments with greater temporal and spatial variability, as variables such as biota, pool size, and distance to the shore contribute to high diurnal changes of temperature, salinity, oxygen concentration and $\mathrm{pH}$. Daily fluctuations in oxygen saturation, alkalinity and $\mathrm{pH}$ have previously been recorded due to biological processes in tide pools (Pyefinch 1943; McGregor 1965; Ganning 1971; Green 1971; Daniel and Boyden 1975; Morris and Taylor 1983). Huggett and Grigffiths (1986) recorded higher oxygen values in the daytime (when photosynthesis is occurring) and lower values at night.

Here, we quantify $\mathrm{pH}$ and carbonate system variability in several intertidal pools representative of intertidal rocky platforms common in the North Atlantic subtropical region, and characterize them in terms of temperature, oxygen concentration, primary productivity and water dynamics. Our main objective was to assess natural in situ $\mathrm{pH}$ values and daily cycles in these habitats, in order to provide information of this geographic area that will inform future ocean acidification studies.

\section{MATERIAL AND METHODS}

To assess temporal and spatial variability of temperature, $\mathrm{pH}$, oxygen concentration and macroalgal and phytoplankton productivity, two intertidal locations were studied at the north of Tenerife, Canary Islands: «Punta del Hidalgo» and «Finca El Apio». Both locations were selected for having large intertidal platforms with large rockpools. Two large intertidal pools with similar characteristics were studied at each site plus 2 small pools with different distances to the subtidal zone, where high resolution temperature data was collected. 


\subsection{Salinity, Temperature and OXYGen CONCENTRATiON}

Oxygen concentrations were measured directly at each pool using a portable $\mathrm{O}_{2}$ sensor (VWR OX $4000 \mathrm{H}$ portable). The $\mathrm{O}_{2}$ sensor was calibrated daily using an open air calibration procedure, as dictated in the manual. Salinity and temperature were measured using a handheld conductimeter (WTW cond 315i). To acquire high resolution temperature data, submersible autonomous data loggers (HOBO Water Temperature Pro v2 Data Logger) were deployed at each pool.

\subsection{PH VARIATION}

To measure daily $\mathrm{pH}$ variability, a moored $\mathrm{pH}$ measuring system was deployed at four of the studied pools (table 1). Each system consisted of a Seabird SBE $18 \mathrm{pH}$ sensor attached to a data logger and a lead battery protected inside a waterproof container. Each system was placed inside a plastic box with several openings to allow water circulation and this box was firmly attached to the bottom of the pool. The $\mathrm{pH}$ sensors were previously calibrated against NIST buffer solutions $(4,7$ and $10 \mathrm{pH} \pm 0.02)$ using the software SEASOFT and its module pHfit. The loggers were programmed to take measurements once every 30 minutes and the systems were deployed for at least 24 hours.

\begin{tabular}{|c|c|c|c|c|c|}
\hline \multicolumn{6}{|c|}{$\begin{array}{l}\text { TABLE 1. CHARACTERISTICS OF THE STUDIED INTERTIDAL POOLS. } \\
\text { PH= «PUNTA DEL HIDALGO»; FA = «INCA DEL APIO». POSITION IS THE RELATIVE } \\
\text { DISTANCE TO THE SUBTIDAL ZONE, FROM CLOSER (1) TO FARTHER (4). } \\
\text { IN BOLD LETTERS, POOLS WHERE THE PH SENSORS WERE DEPLOYED }\end{array}$} \\
\hline Pool & Position & WidTH (m) & Length (m) & Dертн (m) & Volume $\left(\mathrm{m}^{3}\right)$ \\
\hline PH1 & 1 & 7.5 & 20.7 & 2.0 & 310.5 \\
\hline $\mathrm{PH} 2$ & 4 & 7.1 & 15.75 & 0.4 & 44.73 \\
\hline PH3 & 2 & 4.75 & 30.4 & 1.4 & 202.16 \\
\hline PH4 & 3 & 6.8 & 9.4 & 0.35 & 22.37 \\
\hline FA1 & 1 & 4.8 & 14.4 & 1.2 & 82.94 \\
\hline FA2 & 2 & 6.5 & 15.4 & 0.8 & 80.08 \\
\hline FA3 & 3 & 6.2 & 7.0 & 0.6 & 26.04 \\
\hline FA4 & 4 & 4.5 & 8.2 & 0.7 & 25.83 \\
\hline
\end{tabular}

\subsection{CARbon System Parameters}

Seawater total alkalinity (TA) was measured in each of the studied pools using an open cell potentiometric titration with a Metrohm Dosimat 665 titrator using $0.01 \mathrm{~N} \mathrm{HCl}$ with a salinity of about 35 (Dickson et. al 2007). 
The rest of the carbonate chemistry parameters were calculated from TA and $\mathrm{pH}$ using the package seacarb 3.08 for $\mathrm{R}$ (https://cran.r-project.org/web/packages/ seacarb/). Calculations were based on a set of constants, K1 and K2, taken from Lueker et al. (2000).

\subsection{Chlorophyll A Concentration}

Chlorophyll a and phaeopigment concentrations were estimated with a Turner Designs Trilogy fluorometer equipped with an acidification method Chl a module and calculations used the equations from Strickland and Parsons (1972). For each sample, a $1000 \mathrm{ml}$ subsample was filtered on a Millipore polycarbonate $2 \mu \mathrm{m}$ filter to retain the fraction of phytoplankton cells greater than $2 \mathrm{~mm}$, and another $1000 \mathrm{ml}$ subsample was filtered on a Whattmann GF/F glass microfiber filter to retain the total phytoplankton population. Pigments were extracted in $90 \%$ acetone for $24 \mathrm{~h}$ in the dark at $4^{\circ} \mathrm{C}$. The picoplankton pigment concentration was calculated as the difference between the total and $2 \mu \mathrm{m}$ fractions.

\subsection{Primary Production}

Primary production was measured using the ${ }^{14} \mathrm{C}$ method of Steeman-Nielsen (1952) using clear and dark polycarbonate bottles. $4 \mu \mathrm{Ci}$ of $14 \mathrm{C}$ in bicarbonate form were added to each bottle prior to incubation for 4 to 5 hours. After incubation, each bottle was filtered sequentially through filters with pore sizes 2 and $0.7 \mu \mathrm{m}$ (Whattmann GF/F glass microfiber filters). Filters were dried, fumed overnight with $\mathrm{HCl}$ and placed in scintillation vials with $8 \mathrm{ml}$ of Optiphase Hi-Safe scintillation cocktail and measured in a liquid scintillation counter.

\subsection{Macroalgae Productivity}

Padina pavonica was selected to assess its primary productivity, as it was the more abundant species in all of the intertidal pools, making the bulk of the total biomass. Net macroalgae primary productivity and respiration were measured by oxygen production and oxygen depletion after an incubation time. Samples of a wet mass of about $0.300-0.500 \mathrm{~g}$ of $P$. pavonica were selected and placed into a transparent plastic beaker with $100 \mathrm{ml}$ of water taken from the studied pool. Initial $\mathrm{O}_{2}$ concentration was measured with an $\mathrm{O}_{2}$ sensor (VWR OX $4000 \mathrm{H}$ portable) and initial $\mathrm{pH}_{\mathrm{NBS}}$ with a $\mathrm{pH}$ meter (Metrohm mobile meter with a Primatrode NTC IP $\mathrm{pH}$ electrode and temperature sensor), before introducing the sample into the beaker. The beakers were then sealed and placed in the pools for in situ incubations. Beakers for dark respiration measurements were covered with aluminum foil and an extra beaker with no samples was incubated as a blank. Incubations lasted for 2 hours. After the incubation time the samples were removed from the beaker, and final 
$\mathrm{O}_{2}$ concentration and $\mathrm{pH}_{\mathrm{NBS}}$ were measured. Several incubations were performed during the day with the same samples, replacing the water from the incubation vessel. The algae pieces were stored for dry mass determination, drying the samples in the oven at $60^{\circ} \mathrm{C}$ for 48 hours. Dry mass was measured using a precision balance. Net primary production and respiration were calculated as $\mathrm{mg} \mathrm{O}_{2} / \mathrm{g}$ dry mass hour.

\section{RESULTS}

The studied intertidal pools showed a diurnal $\mathrm{pH}$ oscillation, which translated into a $p \mathrm{CO}_{2}$ variation of equivalent magnitude. Daily minimum $\mathrm{pH}_{\mathrm{NBS}}$ levels were obtained early in the morning, at dawn, while maximum $\mathrm{pH}_{\mathrm{NBS}}$ occurred in the afternoon, near the sunset (figure 1). The higher daily variation was detected in «Punta del Hidalgo», where $\mathrm{pH}_{\mathrm{NBS}}$ values oscillated within a range of $0.23 \mathrm{pH}$ units in PH1 and $0.26 \mathrm{pH}$ units in PH3. In this site, the $\mathrm{pH}$ sensors were deployed for two days, allowing the detection of two diurnal cycles. In PH1, the afternoon higher $\mathrm{pH}$ levels measured $\mathrm{pH}_{\mathrm{NBS}} 8.31$ and $\mathrm{pH}_{\mathrm{NBS}} 8.25$, while the daily morning minimum levels were $\mathrm{pH}_{\mathrm{NBS}} 8.08$ and $\mathrm{pH}_{\mathrm{NBS}} 8.09$. In $\mathrm{PH} 3, \mathrm{pH}$ varied from $\mathrm{pH}_{\mathrm{NBS}}$ $8.33-8.38$ as the afternoon values to $\mathrm{pH}_{\mathrm{NBS}} 8.11-8.13$ as the minimum values of the morning. In the other intertidal site, «Finca El Apio», the $\mathrm{pH}$ sensors were deployed for one daily cycle. At this site, the $\mathrm{pH}$ variation range was shorter than in the first site's intertidal pools, probably due to the higher water dynamics present during the sensor deployment. In one of the pools (FA1, figure 1), $\mathrm{pH}_{\mathrm{NBS}}$ varied by only $0.07 \mathrm{pH}$ units during the day, with the afternoon maximum at $\mathrm{pH}_{\mathrm{NBS}} 8.22$ and the early morning minimum at $\mathrm{pH}_{\mathrm{NBS}} 8.16$. The other pool (FA2) produced a higher oscillation, from $\mathrm{pH}_{\mathrm{NBS}} 8.07$ to $\mathrm{pH}_{\mathrm{NBS}} 8.21$.

In pools PH1 and $\mathrm{PH} 2$ at the site located in "Punta del Hidalgo", the increase of $\mathrm{pH}$ detected during the day suffered a perturbation at about 11:00 (fig. 1): the rising tendency of $\mathrm{pH}$ is paused for about 4 hours, coinciding with the high tide reaching the pools, producing the mixing of the pool water with that from the subtidal zone. After this, the rising tendency of $\mathrm{pH}$ during the daytime hours continues till reaching its maximum at the end of the day.

A proportional but inverse variation occurs with $p \mathrm{CO}_{2}$ : high values in the morning and low values in the late afternoon, with the pools at the site in «Punta del Hidalgo» showing more variation than the ones at "Finca El Apio». At PH1, the lower $p \mathrm{CO}_{2}$ numbers were of 192 and $230 \mu$ atm during the studied two days' cycle. The higher, early in the day, $p \mathrm{CO}_{2}$ levels were of $369 \mu \mathrm{atm}$ (a variation of $177 \mu \mathrm{atm}$ ) and $373 \mu \mathrm{atm}$ (a variation of $143 \mu \mathrm{atm}$ ). PH3 showed a higher $p \mathrm{CO}_{2}$ oscillation, similar to that observed in the $\mathrm{pH}$ measurements.

Oxygen concentration showed a daily cycle with lower measurements in the morning and higher $\mathrm{O}_{2}$ concentration at sunset. $\mathrm{O}_{2}$ concentration of $\mathrm{PH} 1$ and $\mathrm{PH} 3$ at sunrise were $7.17 \mathrm{mgO}_{2} / 1$, and $6.94 \mathrm{mgO}_{2} / 1$. respectively. At sunset $\mathrm{O}_{2}$ concentration had reached $7.81 \mathrm{mgO}_{2} / 1$ and $8.01 \mathrm{mgO}_{2} / 1$. At PH1, however, maximum $\mathrm{O}_{2}$ concentration occurred at 10:00 $\left(7.88 \mathrm{mgO}_{2} / \mathrm{l}\right)$, followed with a reduction of $\mathrm{O}_{2}$ concentration to $7.57 \mathrm{mgO}_{2} / \mathrm{l}$, and a further increase at 17:20. This $\mathrm{O}_{2}$ reduction 

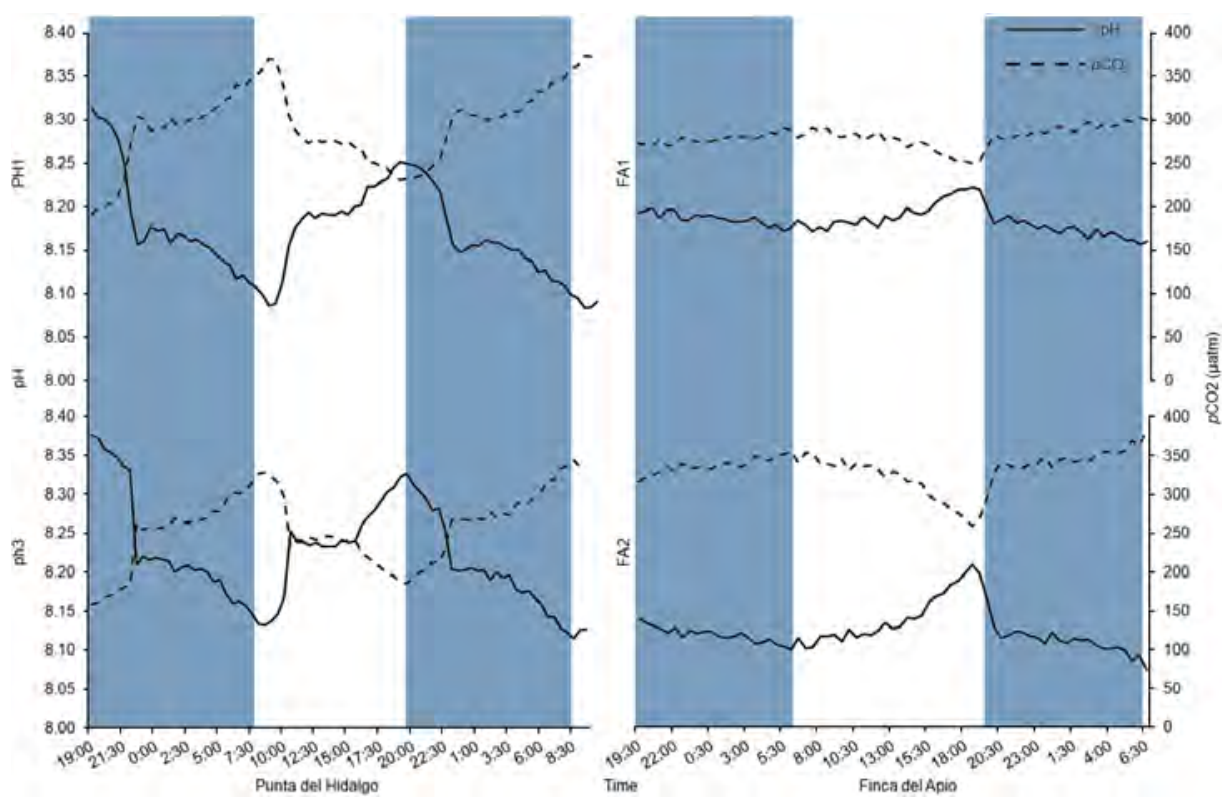

Figure 1 . Daily $\mathrm{pH}$ and $p \mathrm{CO}_{2}$ oscillation at the studied intertidal pools.

The shaded area represents night time.

coincides with the entry of water to the pool due to the high tide. At the "Finca El Apio" site, the morning low $\mathrm{O}_{2}$ concentration data were more elevated than at the intertidal pools of "Punta del Hidalgo» (figure 2), with a maximum data of $7.77 \mathrm{mgO}_{2} / 1$ at FA1 and 8.03 at FA2.

\subsection{WATER TEMPERATURE}

Temperature measurements obtained from sensors located at the pools followed an expected daily pattern, more evident at the smaller pools: lowest temperature at night, which increases after sunrise to a maximum in the afternoon, at 16:00 - 17:00 (figs. 3-4). This is easily observed at PH2 and PH4, with a daily temperature range of $4.67^{\circ} \mathrm{C}$ and $3.31^{\circ} \mathrm{C}$ respectively, compared with a daily range of $0.74^{\circ} \mathrm{C}$ and $1.17^{\circ} \mathrm{C}$ at pools $\mathrm{PH} 1$ and $\mathrm{PH} 3$. Shorter daily temperature ranges were observed at the intertidal pools of "Finca El Apio», 3with daily variations of 0.31 and $0.38^{\circ} \mathrm{C}$ (figure 4). 


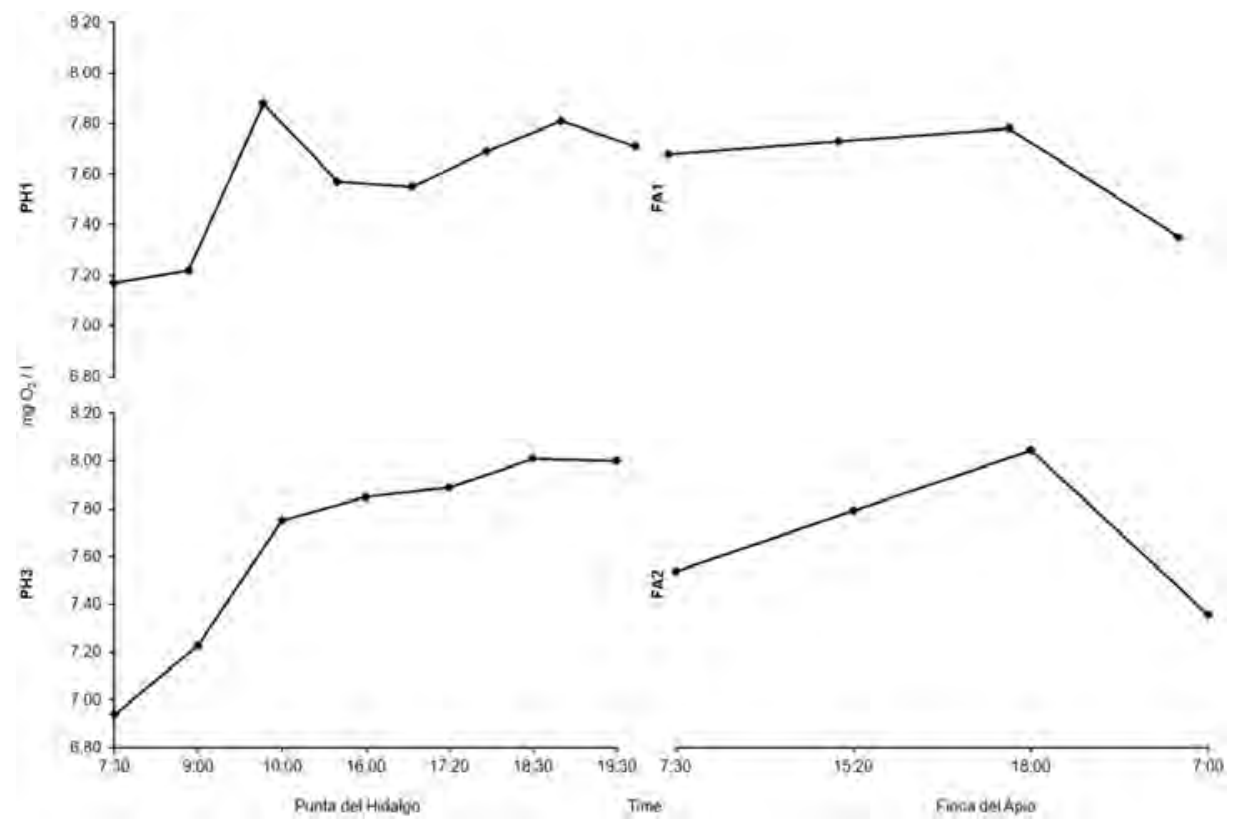

Figure 2. Dissolved oxygen variation at the studied pools.

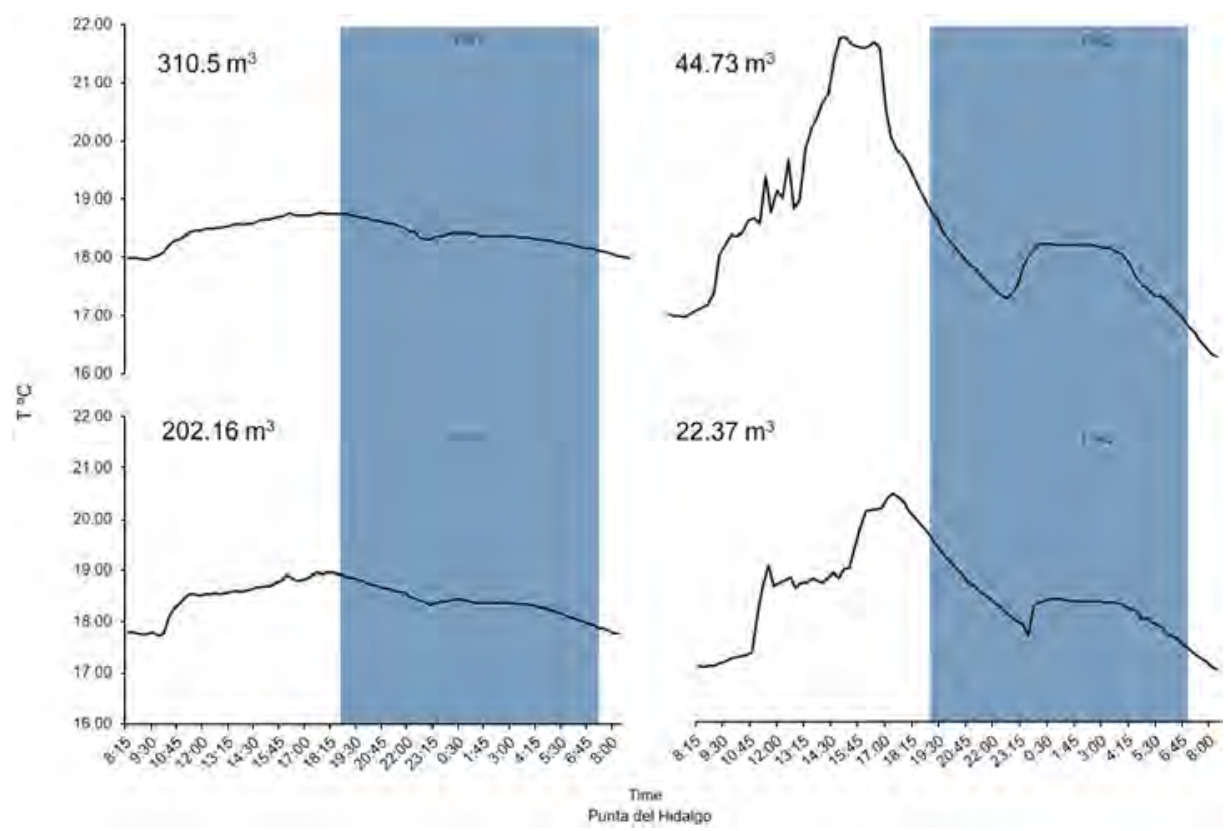

Figure 3. Daily temperature variation of the intertidal pools at location "Punta del Hidalgo». 


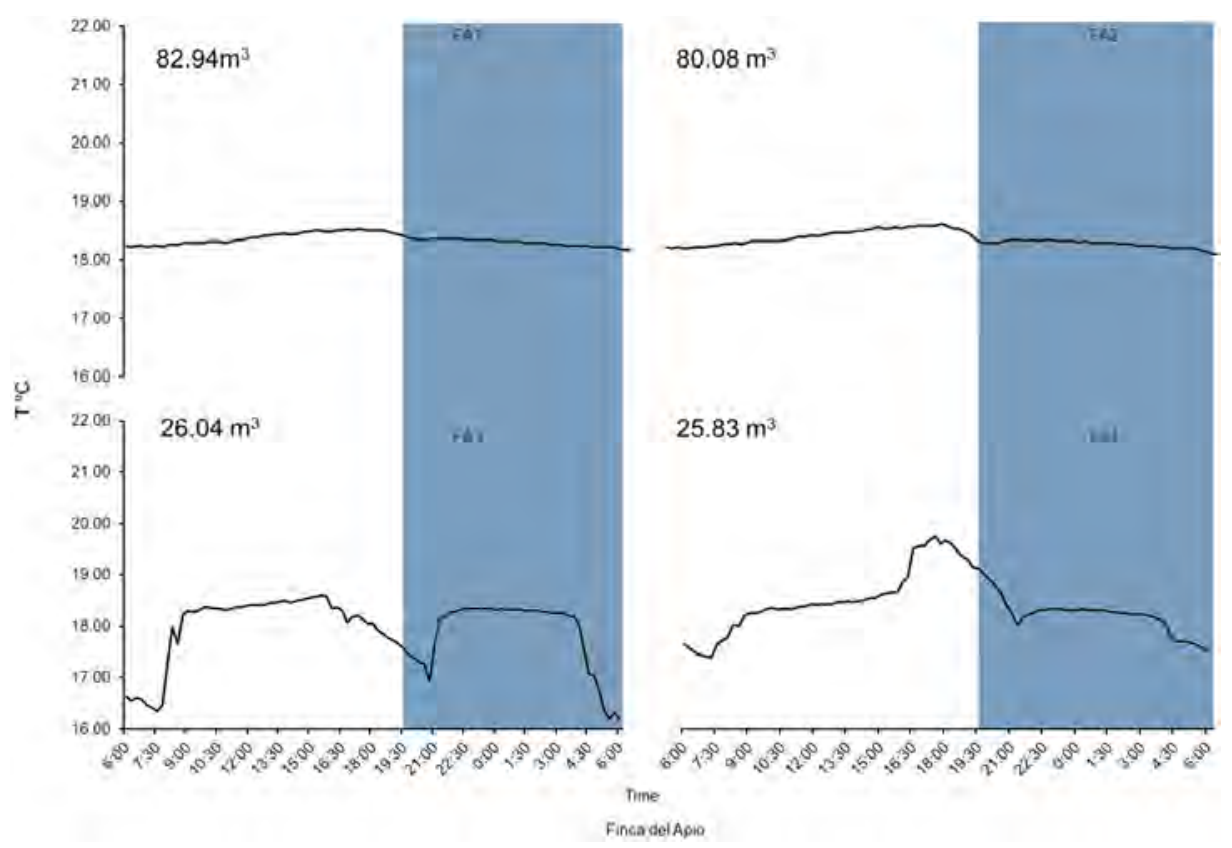

Figure 4. Daily temperature variation of the intertidal pools at location «Finca El Apio».

\subsection{Phytoplankton Biomass and PRODUCtion}

Phytoplankton biomass was estimated using Chla concentration as a proxy. It was higher at the "Finca El Apio» site in both studied fractions of phytoplankton (cells larger than $2 \mu \mathrm{m}$ and cells smaller than $2 \mu \mathrm{m}$ ) (figure 5), where larger cells dominated with [Chla] $>2$ higher than $1.3 \mathrm{mg} / \mathrm{m}^{3}$ and [Chla] $<2$ in the range of $0.20 \mathrm{mg} / \mathrm{m}^{3}$. At «Punta del Hidalgo», [Chla] $>2$ was $0.40 \pm 0.02 \mathrm{mg} / \mathrm{m}^{3}$ at PH1 and $0.24 \pm 0.02 \mathrm{mg} /$ $\mathrm{m}^{3}$ at $\mathrm{PH} 3$. [Chla] $<2$ was $0.18 \pm 0.03 \mathrm{mg} / \mathrm{m}^{3}$ at $\mathrm{PH} 1$ and $0.13 \pm 0.01 \mathrm{mg} / \mathrm{m}^{3}$ at $\mathrm{PH} 3$.

Phytoplankton production was higher at the pools located at «Finca El Apio» (figure 5), where the larger cells were more productive than the smaller than $2 \mu \mathrm{m}$ ones. The size distribution of the phytoplankton production from the pools located at «Punta del Hidalgo» showed that the cells smaller than $2 \mu \mathrm{m}$ were being more productive at both studied pools (figure 5).

\subsection{Macroalgae PRIMARY PRODUCTION}

Padina pavonica was selected to assess its primary productivity, as it was the more abundant species in all of the intertidal pools. This species' mean $\mathrm{O}_{2}$ production was $2.03 \pm 0.39 \mathrm{mgO}_{2} / \mathrm{g}$ dry mass $\mathrm{h}$. No significant differences were observed between 


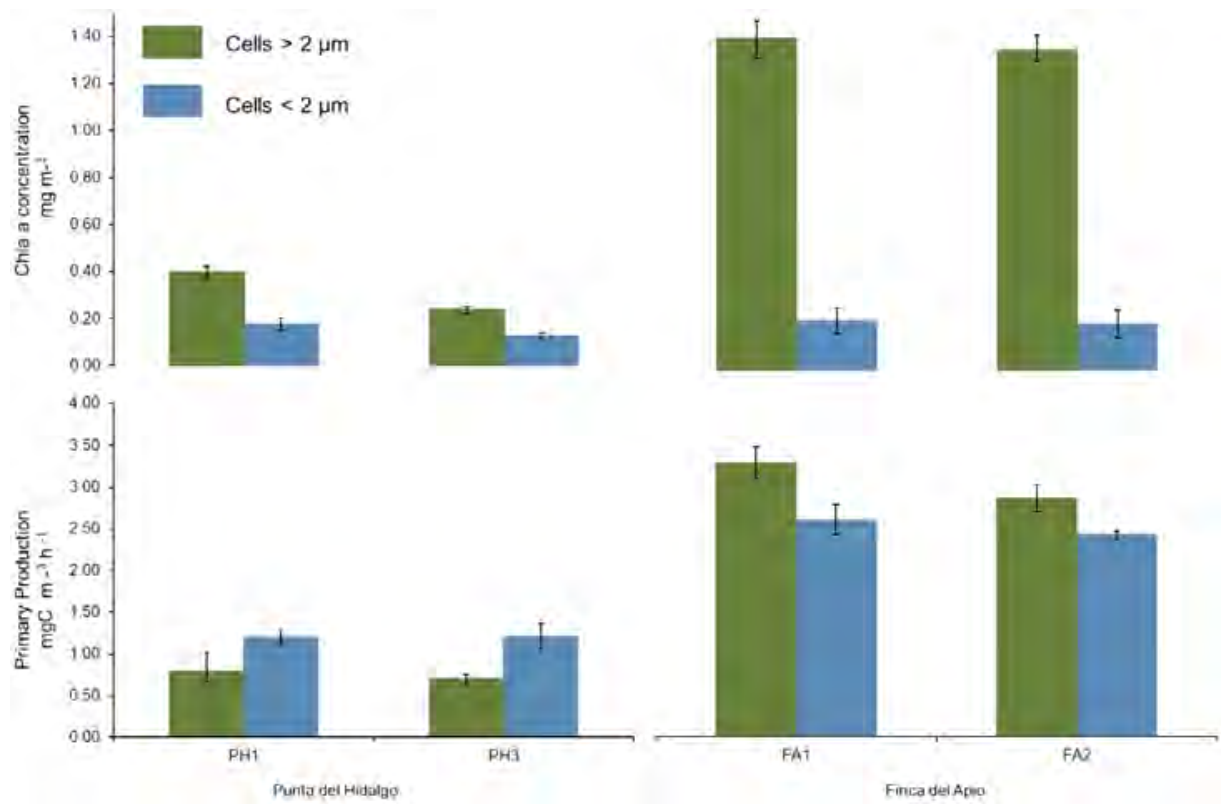

Figure 5. Fractionated phytoplankton chlorophyll a concentration and primary production at the studied pools.

sites (fig. 6). Different incubations were performed in the morning, mid-morning and afternoon, but overall no significant differences were obtained between them. Only at $\mathrm{PH} 3$ of «Punta del Hidalgo» oxygen production from $P$. pavonica was significantly lower at 8:00, the first incubation of the day $\left(1.25 \pm 0.04 \mathrm{mgO}_{2} / \mathrm{g}\right.$ dry mass $\left.\mathrm{h}\right)$.

\section{DISCUSSION}

The results show the carbon system parameters and $\mathrm{O}_{2}$ variability in four large intertidal pools located at two different locations at the North of Tenerife, Canary Islands. A clear diel $\mathrm{pH}$ was recorded by our sensors, driven by the biological activity of the pool's biota, especially primary producers. Typically, intertidal environments suffer constant change: during high tide, seawater floods these areas, but they become isolated when the tide recedes. Metabolic processes play a fundamental role in driving $\mathrm{pH}$ variability: during the day hours, primary producers rise oxygen concentration in seawater through their photosynthetic activity, rising $\mathrm{pH}$ at the same time through its associated inorganic carbon uptake. The sensor measurements reveal that $\mathrm{pH}$ tops at the end of the light hours, when light intensity is not enough to maintain a photosynthetic rate above respiration. Then seawater $\mathrm{pH}$ decreases during night, when $\mathrm{CO}_{2}$ is respired with no carbon uptake occurring. Minimum levels are reached before dawn. The observed range of daily $\mathrm{pH}$ measured at these 


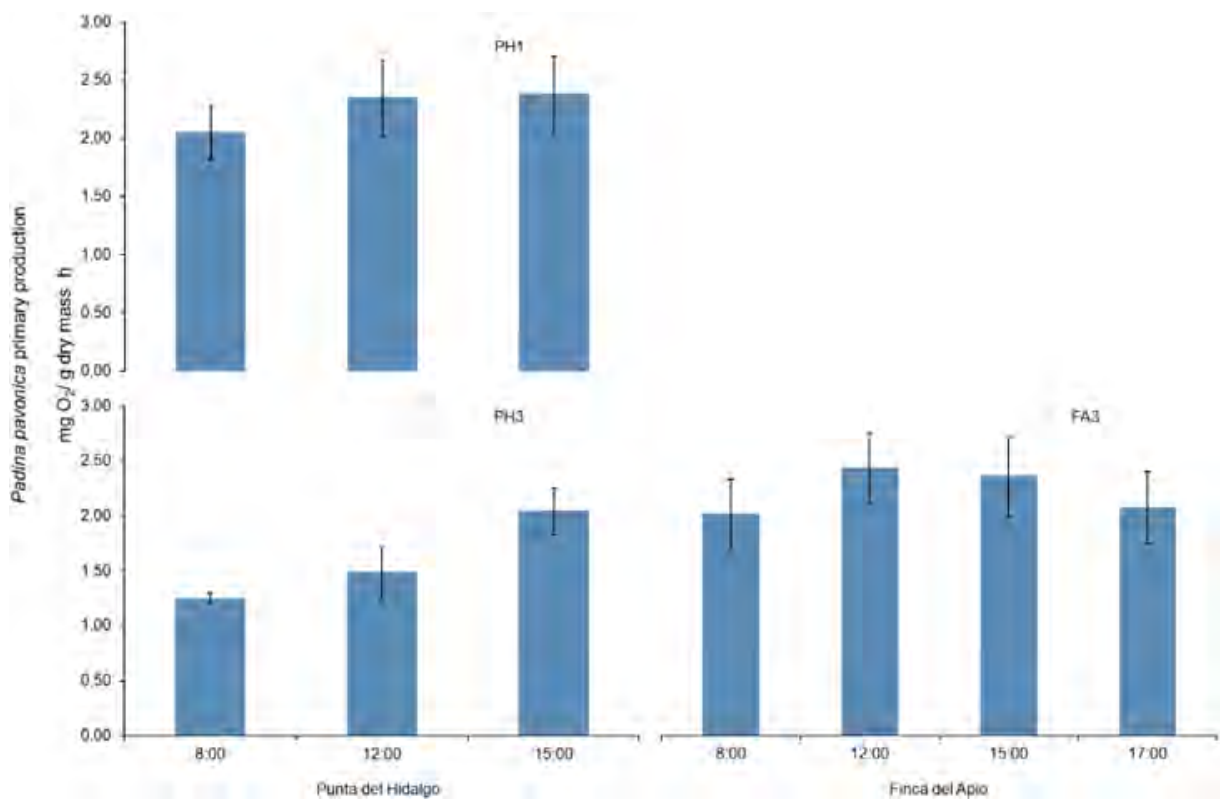

Figure 6. Oxygen production of Padina pavonica at the different studied pools.

intertidal pools encompasses maximums that exceed average ocean $\mathrm{pH}$ before the Industrial Revolution (Jacobson 2005) (8.35 before dusk) and minimums below 8.10, comparable to actual mean ocean $\mathrm{pH}$ (Kleypas 2006). These diurnal $\mathrm{pH}$ fluctuations were comparable to previous observations at subtidal areas of Canary Islands (Hernández et al. 2015), but Variability of $\mathrm{pH}$ and carbon parameters in rockpools communities of Canary Islands had not previously been reported. Other diurnal $\mathrm{pH}$ fluctuations measured at other latitudes were 0.06-0.24 units in shallow seagrass meadow at the Mediterranean (Hendriks et al. 2014), $0.1 \mathrm{pH}$ units/day in spring in the Bay of Calvi in the Mediterranean (Frankignoulle and Bouquegneau 1990) and $0.15 \mathrm{pH}$ units/day in the Bay of Bengal in the Indian Ocean (Subramanian and Mahadevan 1999). At smaller or more productive (denser seaweeds canopy) pools, $\mathrm{pH}$ variability can be much higher. An extreme example, in a subarctic eutrophic area, in small rockpools algal production caused a pHt of 9.0 during the day and pHt of 7.4 at night (Krause-Jensen et al. 2015).

Oxygen concentration rose during the daylight hours driven by photosynthesis, from minimum values before dawn to maximum data before sunset, showing a linear relationship with $\mathrm{pH}$ change. The highest $\mathrm{O}_{2}$ concentration variation range was of $1.07 \mathrm{mg} / \mathrm{l}$ at PH3 at "Punta del Hidalgo», while at FA1 at "Finca El Apio» which was more connected to the subtidal zones, presented a much shorter variation range $(0.1 \mathrm{mg} / \mathrm{l})$. Seawater dynamics were much stronger during the study at this site, keeping the studied pools flooded most of the time which probably caused the 


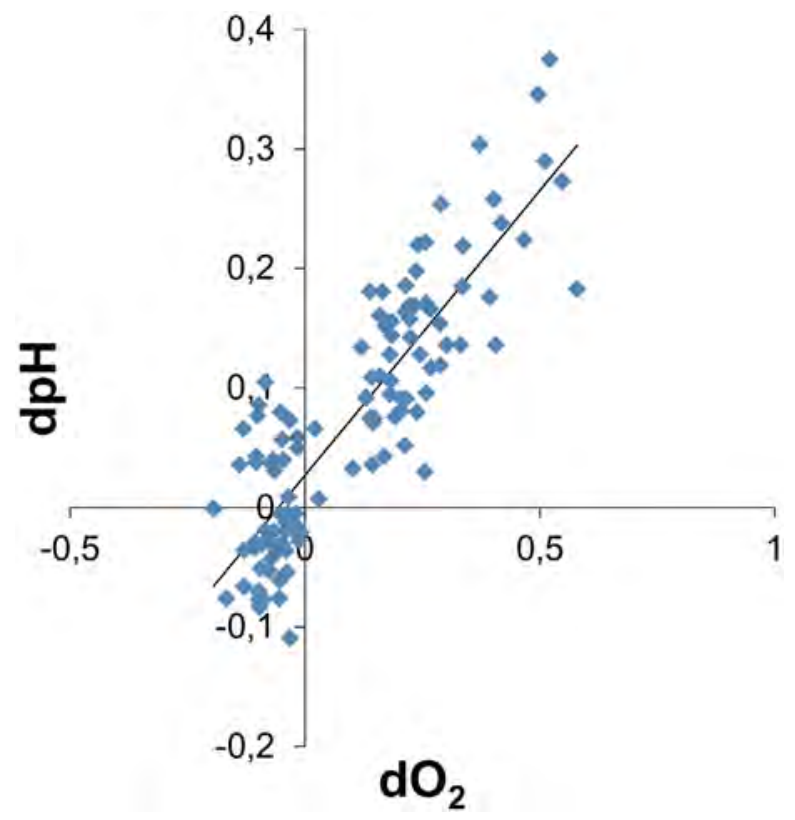

Figure 7. Scatter plot showing oxygen vs $\mathrm{pH}$ variation in the incubation vessels for Padina pavonica.

shorter $\mathrm{pH}$, temperature and oxygen oscillations observed when compared to those at «Punta del Hidalgo». This adds another variation factor at these intertidal ecosystems.

Pool size, primary producers' biomass and water dynamics are the main factors affecting the carbon system dynamics at intertidal pools. A slowdown in $\mathrm{O}_{2}$ concentration and $\mathrm{pH}$ increase was detected at both of the studied pools at «Punta del Hidalgo" (see figures 1 and 2) corresponding to the entry of seawater caused by the high tide. This new water entry affected the temperature cycle as well; being this apparent in the smaller pools (figs. 3-4, PH2 and PH4). The pools with less water volume suffered a wider fluctuation of $\mathrm{pH}$ and temperature. A strong correlation between $\mathrm{O}_{2}$ and $\mathrm{pH}$ variation during incubations for the measurement of macroalgal productivity was detected $\left(\mathrm{R}^{\wedge} 2=0.74\right.$, figure 7$)$, showing that $\mathrm{pH}$ increased with increasing $\mathrm{O}_{2}$ due to photosynthesis and its associated carbon uptake, and that respiration produced the release of carbon, lowering $\mathrm{pH}$.

Phytoplankton did not seem to have an important role in $\mathrm{pH}$ and $\mathrm{O}_{2}$ change during our study. Phytoplankton production was rather high when the «Finca El Apio" area was studied, with primary production data in the range of the highest annual peaks present in oligotrophic areas as the Canary Islands (De Leon and Braun 1973). No significant differences were detected between algal production at both sites, even though a phytoplankton spring bloom was occurring when the sensors were deployed at "Finca El Apio» pools. Diel pH variability was lower at this site's 
pools probably because water dynamics were stronger during measurements at this site, keeping the pool flooded longer, mixing its water with that from the adjacent subtidal zone thus mitigating the concentration of $\mathrm{O}_{2}$ and $\mathrm{pH}$ rise.

This study adds more data about the complexity of carbon chemistry at coastal regions, specifically at intertidal pools. Complexity here is higher than at subtidal zones, as water dynamics, pool size, autotrophic and heterotrophic biomass, distance to the coastline and light irradiance are factors that have important influence over $\mathrm{pH}$ variations. The results of our study suggest that local carbon chemistry should be measured and taken into consideration when designing ocean acidification experiments in preference to the use of regional averages and mimic these natural changes. In order to obtain a diel $\mathrm{pH}$ cycle in laboratory studies for $\mathrm{OA}$, the use of macroalgae in conjunction with light/dark cycle could be viable as a source of $\mathrm{pH}$ variability during experiments.

ReCibIDO: noviembre de 2018, ACEPTADO: noviembre de 2018

\section{ACKNOWLEDGEMENT}

To José Carlos Mendoza who helped during the field work.

\section{AUTHORS' CONTRIBUTION}

Conceptualization: $\mathrm{CH}$, JCH.

Methodology and field work: $\mathrm{CH}, \mathrm{JCH}$.

Data analysis: $\mathrm{CH}$, JCH.

Original draft: $\mathrm{CH}$.

Review and edition of the final draft: $\mathrm{CH}, \mathrm{JCH}$. 


\section{REFERENCES}

Canadell, J., Le Quéré, C., Raupach, M.R., Fields, C., Buitenhuis, E.T., Ciais, P., Conway, T.J., Gillett, N.P., Houghton, R.A. and Marland, G. 2007. Contributions to accelerating atmospheric $\mathrm{CO}_{2}$ growth from economic activity, carbon intensity, and efficiency of natural sinks. P. Natl. Acad. Sci. USA. 104: 18866- 18870.

Daniel, M.J. and Boyden, C.R. 1975. Diurnal variations in physico-chemical conditions within intertidal rockpools. Fld. Stud. 4: 161-176.

De León, A.R. and Braun, J.G. 1973. Ciclo anual de la producción primaria y su relación con los nutrientes en aguas canarias. Bol. Inst. Esp. Oceanogr. 167: 1-24.

Doney, S.C., Fabry, V.J., Feely, R.A., Kleypas, J.A. 2009. Anthropogenic ocean acidification over the twenty-first century and its impact on calcifying organisms. Annu. Rev. Mar. Sci. 1: 169-192.

Doney, S.C., Ruckelshaus, M., Duffy, J.E., Barry, J.P., Chan, F., English, C.A., Galindo, H.M., Grebmeier, J.M., Hollowed, A.B., Knowlton, N., Polovina, J., Rabalais, N.N., Sydeman, W.J. and Talley, L.D. 2012. Climate Change impacts on marine ecosystems. Annu. Rev. Mar. Sci. 4: 11-37.

Duarte, C.M., Hendriks, I.E., Moore, T.S., Olsen, Y.S., Steckbauer, A., Ramajo, L., Carstensen, J., Trotter, J.A. and McCulloch, M. 2013. Is ocean acidification an open-ocean syndrome? Understanding anthropogenic impacts on seawater $\mathrm{pH}$. Estuar Coast. 36(2): 221-236.

Dupont, S., Dorey, N., Stumpp, M., Melzner, F. and Thorndyke, M. 2013. Long-term and trans-life-cycle effects of exposure to ocean acidification in the green sea urchin Strongylocentrotus droebachiensis. Mar. Biol. 160: 1835-1843.

Fabry, V.J., Seibel, B.A., Feely, R.A. and OrR, J.C. 2008. Impacts of ocean acidification on marine fauna and ecosystem processes. ICES J. Mar. Sci. 65(3): 414-432.

Fine, M. and Tchernov, D. 2007. Scleractinian coral species survive and recover from decalcification. Science. 315: 1811.

Frankignoulle, M. and Bouquegneau, J.M. 1990. Daily and Yearly Variations of Total Inorganic Carbon in a Productive Coastal Area. Estuar. Coast. Shelf. S. 30: 79-89.

Frankignoulle, M. and Distèche, A. 1987. $\mathrm{CO}_{2}$ chemistry in the water column above a Posidonia seagrass bed and related air-sea exchanges. Oceanol. Acta. 7: 209-219.

Ganning, B. 1971. Studies of chemical, physical and biological conditions in Swedish rockpool ecosystems. Ophelia. 9: 51-105.

Gattuso, J.P. and Hansson, L., (eds.) 2011. Ocean Acidification. Oxford: Oxford University Press. 352 p.

Green, J.M. 1971. Local distribution of Oligocottus maculosus Girard and other tidepool cottids of the west coast of Vancouver Island, British Columbia. Can. J. Zool. 49: 1111-1128.

Gruber, N., Hauri, C., Lachkar, Z., Loher, D., Frölicher, T.L. and Plattner, G.K. 2012. Rapid progression of ocean acidification in the California current system. Science. 337: 220-223.

Hall-Spencer, J.M., Rodolfo-Metalpa, R., Martin, S., Ransome, E., Fine, M., Turner, S.M., Rowley, S.J., Tedesco, D. and Buia, M.C. 2008. Volcanic carbon dioxide vents show ecosystem effects of ocean acidification. Nature. 454(7200): 96-99. 
Hernández, C.A., Clemente, S., Sangil, C. and Hernández, J.C. 2015. High-resolution ocean $\mathrm{pH}$ dynamics in four subtropical Atlantic benthic habitats. Biogeosciences Discuss. https:// doi.org/10.5194/bgd-12-19481-2015.

Hofmann, G.E., Smith, J.E., Johnson, K.S., Send, U., Levin, L.A., Micheli, F., Paytan, A., Price, N.N., Peterson, B., Takeshita, Y., Matson, P.G., Crook, E.D., Kroeker, K.J., Gambi, M.C., Rivest, E.B., Frieder, C.A., Yu, P.C. and Martz, T.R. 2011. High-Frequency Dynamics of Ocean pH: A Multi-Ecosystem Comparison. PLoS ONE. 6(12): e28983.

Houghton, J.T., Ding, Y., Griggs, D.J., Noguer, M., Van Der Linden, P.J. and Xiaosu, D., eds. 2001. Climate Change 2001: The Scientific Basis: Contributions of Working Group I to the Third Assessment Report of the Intergovernmental Panel on Climate Change. Cambridge. Cambridge University Press. 892 p.

Huggett, J. and Griffiths, C.L. 1986. Some relationships between elevation, physico-chemical variables and biota of intertidal rock pools. Mar. Ecol. Prog. Ser. 29: 189-197.

Invers, O., Romero, J. and Pérez, M. 1997. Effects on seagrass photosynthesis: a laboratory and field assessment. Aquat. Bot. 59: 185-194.

Pachauri, R.K. and Meyer, L.A. (eds.) 2014. Climate Change 2014: Synthesis Report.Contribution of Working Groups I, II and III to the Fifth Assessment Report of the Intergovernmental Panel on Climate Change. Geneva, Switzerland IPCC, 151 pp.

Jacobson, M.Z. 2005. Studying ocean acidification with conservative, stable numerical schemes for nonequilibrium air-ocean exchange and ocean equilibrium chemistry. J. Geophys. Res. 110, D07302, doi: 10.1029/2004JD005220.

Kleypas, J.A., Feely, R.A., Fabry, V.J., Langdon, C., Sabine, C.L. and Robbins, L.L. 2006. Report of a workshop sponsored by NSF, NOAA, and the U.S. Geological Survey. In: Impacts of ocean acidification on coral reefs and other marine calcifiers: a guide for future research. St. Petersburg, FL. p. 88.

Kleypas, J.A., Feely, R.A., Fabry, V.J., Langdon, C., Sabine, C.L. and Robbins, L.L. 2006. Impacts of ocean acidification on coral reefs and other marine calcifiers: A guide for future research. Contribution No. 2897 from NOAA/Pacific Marine Environmental Laboratory.

Krause-Jensen, D., Duarte, C.M., Hendriks, I.E., Meire, L., Blicher, M.E., Marbà, N. and SEJR, M.K. 2015. Macroalgae contribute to nested mosaics of $\mathrm{pH}$ variability in a sub-Arctic fjord. Biogeosciences. 12: 4895-4911.

Kroeker, K.J., Kordas, R.L., Crim, R.N. and Singh, G. 2013. Meta-analysis reveals negative yet variable effects of ocean acidification on marine organisms. Ecol. Lett. 13: 1419-1434.

Kroeker, K.J., Micheli, F., Gambi, M.C. and Martz, T.R. 2009. Divergent ecosystem responses within a benthic marine community to ocean acidification. Proc Natl Acad Sci USA. 108: 14515-14520.

Le Quéré, C., Raupach, M.R., Canadell, J.G., Marland, G., Bopp, L., Ciais, P., Conway, T.J., Doney, S., Feely, R.A., Foster Pru, Friedlingstein, P., Gurney, K., Houghton, R.A., House, J.I., Huntingford, C., Levy, P.E., Lomas, M.R., Majkut, J., Metzl, N., Ometto, J.P., Peters, J.P., Prentice, I.C., Randrson, J.T., Running, S.W., Sarmiento, J.L., Schuster, U., Sitch, S., Takahasi, T., Viovy, N., van der Werf, G.R. and WoodWARD, F.I. 2009. Trends in the sources and sinks of carbon dioxide. Nat. Geosci. 2: 831-836. 
Lueker, T.J., Dickson, A.G. and Keeling, C.D. 2000. Ocean $p \mathrm{CO}_{2}$ calculated from dissolved inorganic carbon, alkalinity, and equations for $\mathrm{K} 1$ and $\mathrm{K} 2$ : validation based on laboratory measurements of $\mathrm{CO}_{2}$ in gas and seawater at equilibrium. Mar. Chem. 70: 105-119.

McElhany, P. and Busch, D.S. 2013. Appropriate $p \mathrm{CO}_{2}$ treatments in ocean acidification experiments. Mar. Biol. 160: 1807-1812.

McGregor, D.D. 1965. Physical ecology of some New Zealand rockpools. Hydroblologia. 25: 277-284.

Meehl, G.A., Collins, W.D., Friedlingstein, P., Gaye, A.T., Gregory, J.M., Kitoh, A., Knutti, R., Murphy, J.M., Noda, A., Raper, S.C.B., Watterson, I.G., Weaver, A.J. and Zнао, Z. 2007. The physical science basis. In: climate change. IPCC report, pp. 748-845. Cambridge, UK: Cambridge University Press.

Mercado, J.M. and Gordillo, F.J.L. 2011. Inorganic carbon acquisition in algal communities: are the laboratory data relevant to the natural ecosystems? Photosynth. Res. 109: 257-267.

Metaxas, A. and Scheibling, R.E. 1993. Community structure and organization of tide pools. Mar. Ecol. Prog. Ser. 98: 187-198.

Middelboe, A. and Hansen, P.J. 2007. High pH in shallow-water macroalgal habitats. Mar. Ecol. Prog. Ser. 338: 107-117.

Morris, S. and TAYlor, A. C. 1983. Diurnal and seasonal variation in physico-chemical conditions within intertidal rock pools. Estuar. Coast. Shelf. S. 17: 339-355.

Nielsen, E. 1952. Use of radioactive carbon $\left({ }^{14} \mathrm{C}\right)$ for measuring organic production in the sea. ICES J. Mar. Sci. 18: 117-140.

Orr, J.C., Fabry, V.J., Aumont, O., Bopp, L., Doney, S.C., Feely, R.A., Gnanadesikan, A., Gruber, N., Ishida, A., Joos, F., Key, R.M., Lindsay, K., Maier-Reimer, E., Matear, R., Monfray, P., Mouchet, A., NajJar, R.J., Plattner, G.K., Rodgers, K.B., Sabine, C.L., Sarmiento, J.L., Schlitzer, R., Slater, R.D., Totterdell, I.J., Weirig, M.F., YamanaKa, Y. and Yool, A. 2005. Anthropogenic ocean acidification over the twenty-first century and its impact on calcifying organisms. Nature. 437: 681-686.

Pyefinch, K.A. 1943. The intertidal ecology of Bardsey Island, North Wales, with special reference to the recolonization of rock surfaces, and the rock-pool environment. J. Anim. Ecol. 12: 82-108.

Ries, J.B., Cohen, A.L. and McCorkle, D.C. 2009. Marine calcifiers exhibit mixed responses to $\mathrm{CO}_{2}$-induced ocean acidification. Geology. 37: 1131-1134.

Royal Society. 2005. Ocean Acidification due to Increasing Atmospheric Carbon Dioxide. Policy document 12/05 Royal Society, London. The Clyvedon Press Ltd., Cardiff.

Semesi, I.S., BeER, S. and BJörk, M. 2009. Seagrass photosynthesis control rates of calcification and photosynthesis of calcareous macroalgae in a tropical seagrass meadow. Mar. Ecol. Prog. Ser. 382: 41-47.

Strickland, J.D.H. and Parsons, T.R. 1972. A Practical Handbook of Seawater Analysis, Bulletin 167, 2nd Edition. Bull. Fish. Res. Board. Can. 310.

Subramanian, B. and Mahadevan, A. 1999. Seasonal and diurnal variation of hydrobiological characters of coastal water of Chennai (Madras), Bay of Bengal. Indian. J. Mar. Sci. 28(4): 429-433. 